\title{
Control of Ore Loss and Dilution at AngloGold Ashanti, Iduapriem Mine using Blast Movement Monitoring System*
}

\author{
P. A. Eshun and K. A. Dzigbordi
}

Eshun, P. A. and Dzigbordi, K. A. (2016), "Control of Ore Loss and Dilution at AngloGold Ashanti, Iduapriem Mine using Blast Movement Monitoring System”, Ghana Mining Journal, Vol. 16, No. 1, pp. 49 - 59.

\begin{abstract}
Blast Movement Monitoring (BMM) system is a new method of determining material movement during blasting in order to minimise ore loss, dilution and sometimes misclassification. The BMM system was introduced at AngloGold Ashanti Iduapriem (AAIL) Mine in the first quarter of 2013 as a result of reconciliation challenges at the start of operation at the Ajopa Pit in the first quarter of 2012. Since the introduction, there has been improvement in reconciliation, but the cost implication became worth assessing because of dwindling gold price. The main objective of this paper, therefore, is to assess the benefits or otherwise of BMM system on blast induced movement at Iduapriem Mine. The study comprises data collection on BMM system at AAIL and its analysis, as well as cost and benefit analysis. From the BMM data analysis, it was observed that, the bottom flitch of the blasted material moved more than the top flitch in the horizontal direction while the reverse was the case for the vertical movement. The cost-benefit analysis from four shots analysed revealed that there was a benefit of $\$ 753835$ which translates into $650 \%$ return on investment. Thus, the use of the BMM system has positive financial impact on Iduapriem Mine. Continuous use of the system as a grade control practice has, therefore, been recommended for the Mine, especially with shots containing ore. Furthermore, a dedicated team for this task has been recommended to enhance efficiency. Finally, high precision GPS has been suggested to be added to the detector instrument to make surveying of pre-blast and post-blast BMM points easier and faster.
\end{abstract}

Keywords: Blast Movement Monitoring System, Ore Loss, Dilution, Misclassification, Reconciliation

\section{Introduction}

Blasting causes movement of the rock and can be detrimental to the accurate delineation of the ore and waste regions within the resulting muckpile. The consequences can be post-blast ore loss (moving ore to waste dump), dilution (mining waste with ore), and misclassification (part of a block moving into another block).

Reducing the amount of ore loss and dilution of Run-of-Mine (ROM) ore prior to processing is the goal of most metal mining companies. The addition of waste to ROM ore for processing as a result of blast movement lowers the overall expected mill head grade. This could lead not only to poor reconciliation but also affect the economic viability of the mining business. Costly extensive grade control drilling, assaying and time consuming computerised orebody modelling become meaningless if the pre-blast ore perimeters defined are not translated after blasting before excavation, to account for blast movement. Therefore, ore loss and dilution can be minimised and significant increases in profit can be realised if the movement of the blast can be accurately measured.

Over the years, AngloGold Ashanti Iduapriem Limited (AAIL) has had challenges with grade and tonnage reconciliation of material mined from its pits, especially the Ajopa pit. There was about $10 \%$ drop in the accountable metal from the start of mining at Ajopa from October, 2012 to the 1st quarter of 2013.

One way of addressing this challenge was the introduction of the Blast Movement Monitoring (BMM) system to monitor the movement of the ore after blasting and also to adjust the ore outlines before mining. However, the cost implication became a matter of concern as a result of dwindling gold price. This paper therefore presents a study of the BMM system at AngloGold Ashanti Iduapriem Mine and an assessment of the benefits or otherwise of the system to the Mine.

\subsection{About the Study Area}

\subsubsection{Location and Accessibility}

AngloGold Ashanti Iduapriem Limited (AAIL) is a subsidiary of AngloGold Ashanti Company. It comprises two properties i.e. Iduapriem and Teberebie. Both properties are located in the Western Region of Ghana, some $70 \mathrm{~km}$ north of Takoradi, the Regional capital and $10 \mathrm{~km}$ southwest of Tarkwa. It is $233 \mathrm{~km}$ from Kumasi, the second largest city in Ghana and about $322 \mathrm{~km}$ from Accra, the national capital. AAIL is located along the southern end of the Tarkwa basin (Anon., 2013). The mine is accessible by road from Kumasi and Takoradi. Fig. 1 shows the location of AAIL on the map of Ghana. 


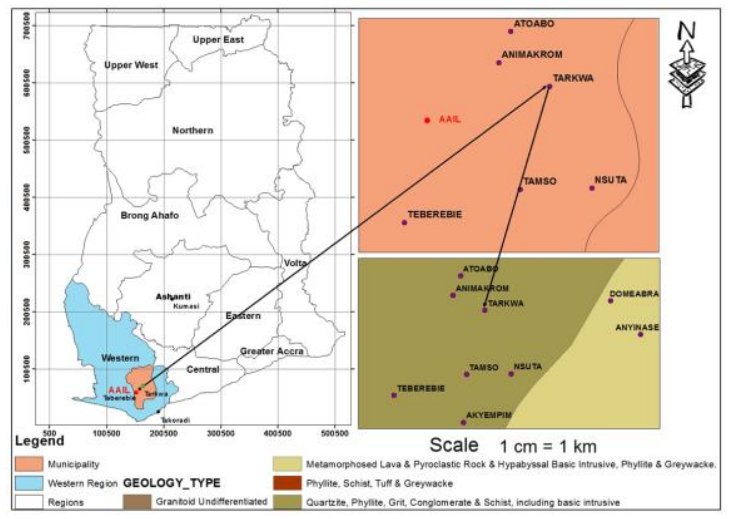

Fig. 1 Map of Ghana showing the Location of AAIL (Source: Authors' Construct)

\subsubsection{Physiography}

The relief of the area is characterised by series of undulating landscape with prominent ridges that are about 60 to 80 metres above mean sea level (Anon., 2013). The ridges which form the four main specific mining areas are: Blocks 1 to 5; Block 6 (Ajopa); Blocks 7 (Teberebie); and 8 (Awunaben). Fig. 2 is a map of a section of the Tarkwa district showing the Iduapriem mining lease.

\subsubsection{Deposit Geology}

All gold mineralisation occurs within the four specific zones or reefs and are not related to metamorphic and hydrothermal alteration events. The gold is fine-grained, particulate and free milling (i.e. not locked up with quartz or iron oxides). Mineralogical studies indicate that the grain size of native gold particles ranges between 2 and $500 \mu \mathrm{m}$ and averages $130 \mu \mathrm{m}$. Sulphide mineralisation is present only at trace levels and is not associated with the gold (Baffoe, 2004).

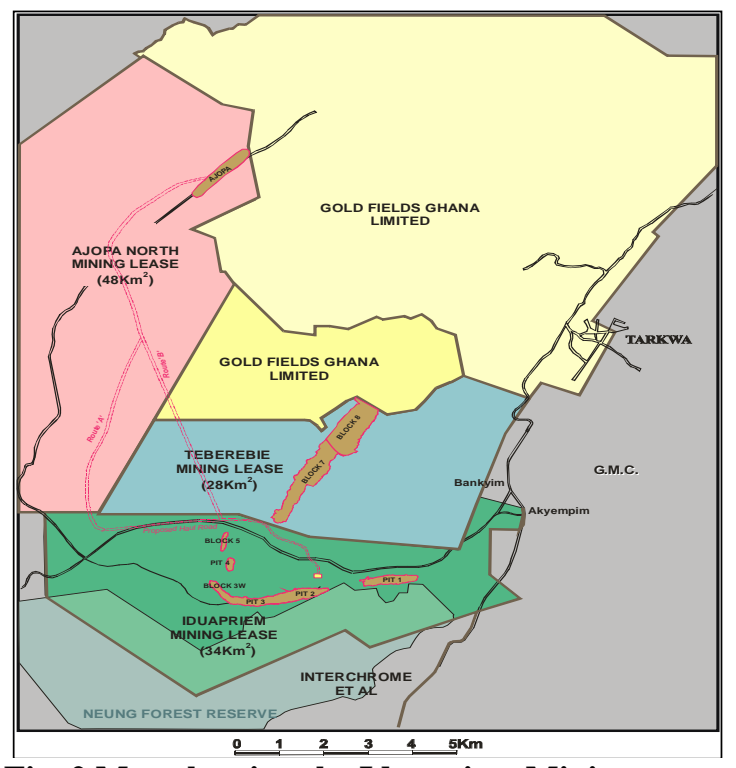

Fig. 2 Map showing the Iduapriem Mining Lease (Source: Anon., 2013)

\subsubsection{Mining Operations}

Mining operations are conducted using conventional open pit mining method. This employs four standard unit operations namely drilling, blasting, loading and hauling. At the time of the study, mining operations were contracted to AMS Limited, a subsidiary of the Ausdril Group of companies in Australia.

The drilling operations are done by AMS employing three (3) Pantera, four (4) Rock Commander, and two (2) Drilltech drill rigs. Drilling parameters include $6 \mathrm{~m}$ bench height with $1 \mathrm{~m}$ sub-drill and hole diameter of $127 \mathrm{~mm}$ for production holes and $102 \mathrm{~mm}$ for pre-split. The current blast pattern is staggered with $4.2 \mathrm{~m}$ burden by $4.6 \mathrm{~m}$ spacing for both ore and waste. Blasting employs down-the-hole delay firing using electric initiation system. Explosives and accessories are supplied by Maxam Ghana Limited. Powder factor is normally around $0.52 \mathrm{~kg} / \mathrm{m}^{3}$.

At Ajopa pit, the load and haul operation is carried using one (1) Liebherr 9250 excavator and one (1) Liebherr 984 excavator as back-up with eight (8) 92-tonne capacity haul trucks. Two (2) of the 8 trucks are mostly on stand-by. The material is mined and dumped onto a stockpile at Ajopa by AMS and later transported by Maxmass Company, a local contractor, to the crushing plant. Maxmass uses FM400 Volvo Tipper trucks for the rehandling.

\subsection{Blast Movement Monitoring}

The aim of rock excavation in an open pit mine is to produce an optimum mill feed with minimum dilution to maximise recovery at a minimum operating cost. Little and Van Rooyen (1988) were among the first to identify blast-induced dilution as a significant grade control problem.

A number of sites and research institutions have used a range of measurement techniques with varying success. These can be categorised by the type of marker employed: passive visual ones such as sand bags, chains and pipe; and remote detection systems such as blast movement monitors and magnetic markers that can be detected prior to excavation of the blasted ore (La Rosa and Thornton, 2011).

Yang and Kavetsky (1989) developed a twodimensional model with a simple kinematic approach for predicting the muckpile shape in bench blasting. This model could be calibrated in a straight-forward manner using the blast parameters and the results could be used to analyse alternative blasting designs. They further developed an extension to the model in 1990 which resulted in a 
three-dimensional model of muckpile formation and grade boundary movement in bench blasting. These models include the blast design geometry, initiation, and explosive energy. Limited data from a case study were used to calibrate the models.

Lucas and Nies (1990) implemented two programmes at Homestake McLaughlin Mine; one to minimise the ore displacement, ground vibration and maintain good fragmentation with sequential timing, and the second to evaluate the orientation of delay pattern to the apparent rock structure. By reducing the powder factor in proportion with small blast holes, the explosives energy distribution was accomplished.

Zhang (1994) and Zhang et al., (1994) investigated the blast-induced rock movement and its impact on grade control at Rain mine and Coeur Rochester mine. Six blasts at Rain mine and twelve blasts at Coeur mine were monitored. The study found out that:

(i) The powder factor and the magnitude of the movement of the blast pattern were directly related; and

(ii) The primary horizontal blast movement direction was approximately parallel to the initiation direction of each blast.

Zhang et al., (1994) also suggested that in order to minimise the grade dilution, it is necessary to direct the blast in the deposit's strike direction with a single initiation point.

Taylor (1995) proposed the survey of pre and postblast positions of solid marker objects. Solid markers are bags filled with rock-dust and placed in blast holes within the bench. Extra holes were drilled along with the normal drill holes with their known pre-blast locations. Usually these extra holes were drilled near the ore/waste boundary. The marker bags were placed in the extra holes which were devoid of explosives. After the blast, the rock was excavated and the post-blast positions of the bags were surveyed.

Taylor's method has some disadvantages which limit its effectiveness. It is labour intensive and time consuming, particularly the post-blast survey, extra drill holes are needed which increases the drilling cost. There can be low recovery of the markers due to:

(i) Difficulty in seeing the bags in the muckpile during the night shift;

(ii) Incorrect identification of marker bags by shovel operators;

(iii) Delayed movement information for correcting the digging polygons; and

(iv) Efficiency of the technique is dependent on the ability of the shovel operators to discover the targets in the muckpile after the blast.
In 2004, Adam and Thornton described that the movement of ore within a blast can have significant economic impact on open pit mines. Blasting of the valuable mining blocks causes movement of the rock and is detrimental to the accurate delineation of the ore and waste regions within the muckpile. They used the electronic blast movement monitor developed by Julius Kruttschnitt Mineral Research Center (JKMRC), which provides 3-dimensional movement vectors following a production blast. With this information, the ore block boundaries in the blasted bench were adjusted to compensate for the measured movement and ore recovery. They concluded that "the development of JKMRC Blast Movement Monitors (BMM®s) showed the system to be reliable, easy to use and predict the blast movement (Adam and Thornton, 2004).

In 2005, the Blast Movement Monitoring (BMM) was conducted by Placer Dome Inc., at Porcupine mine (Yennamani, 2010). The major considerations while designing BMM holes were the size and shape of the pattern, the amount and location of ore and the direction of the blast. The BMM®s were used on a regular basis almost in every blast containing ore. It was observed that the direction of the movement was fairly predictive but the distance of the movement had some significant variations.

Research at the University of Queensland resulted in the development of an active blast movement marker (Thornton, et al., 2005; Thornton, 2009a and Thornton, 2009b) and subsequent commercialisation by Blast Movement Technologies (BMT). According to Loeb and Thornton (2014), "an innovative technology has been developed and commercialised so that open pit mine operation personnel can measure three dimensional movement in every production blast".

As concluded by La Rosa and Thornton (2011), "there is an increasing awareness of the magnitude and variation of blast movement and its economic implications. Since practical methods are now available to routinely measure blast movement, there is a compelling case for all mines to include blast movement measurement into their grade control procedures".

In Ghana Engmann et al. (2013) validated the use of BMM system at Newmont Ghana Gold Ltd, Ahafo Mine. This paper studies the application of the system at AngloGold Ashanti, Iduapriem Mine and conducts cost-benefit analysis of the implementation of the system.

\subsection{BMM System Instrumentation}

The measurement and analysis of rock movement using BMM system require the following equipment: 
(i) $\mathrm{BMM}{ }^{\circledR}$ Ball (Sensor);

(ii) $\mathrm{BMM}{ }^{\circledR}$ Activator;

(iii) GP5200 BMM® Detector;

(iv) Survey equipment (GPS, Total Station, etc.); and

(v) A computer with MS Office, Datamine or Surpac and BMM Explorer (Assistant) Software.

\subsubsection{Blast Movement Monitor (BMM®) Ball}

The BMM® ball shown in Fig. 3 is made of Acrylonitrile-Butadiene-Styrene (ABS) plastic and contains a directional radio signal transmitter. It is a $98 \mathrm{~mm}$ diameter ball that is dropped in a dedicated non-blast hole within the blast pattern. BMM drill holes are normally planned between production holes (drilled holes for charging and blasting).

Two BMM®s are dropped in a hole but maximum of 4 could be installed in a hole. In the case of two balls, one is to measure the top flitch movement and the other the bottom flitch movement. It is worth mentioning that BMM® balls are not reusable.

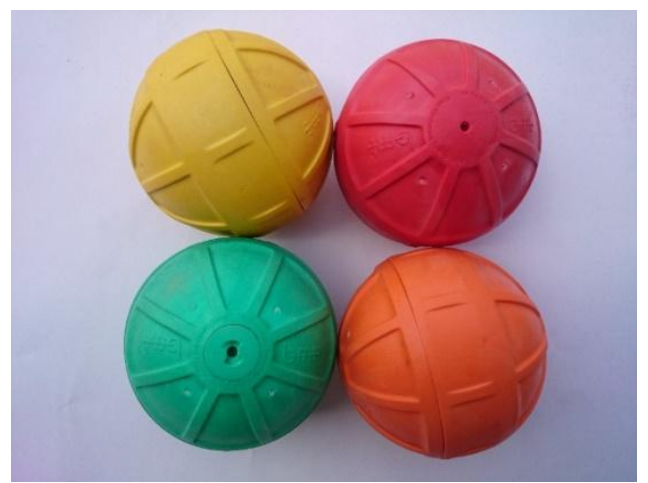

Fig. 3 Blast Movement Monitor (BMM®) Balls (Anon., 2015)

\subsubsection{BMM® Activator}

The BMM $®$ activator is a hand held remote control device that provides the signal not only to turn the transmitter on but also to assign a delayed startup/transmission time. It is also used to quickly determine or test if a $\mathrm{BMM} \circledast$ ball is transmitting signals. The BMM ${ }^{\circledR}$ activator consists of a tough ABS plastic case with a sealed low-profile keypad and supplied with a rubber boot for added protection. Fig. 4 shows the activator.

The following are parts of BMM® ball activator:

(i) Power button (black);

(ii) Set delay button (yellow);

(iii) $\mathrm{BMM} ®$ activator (green);

(iv) Signal test on/off button (grey);

(v) Delay time (orange);

(vi) Transmit LED (green); and

(vii)Receive LED (red).

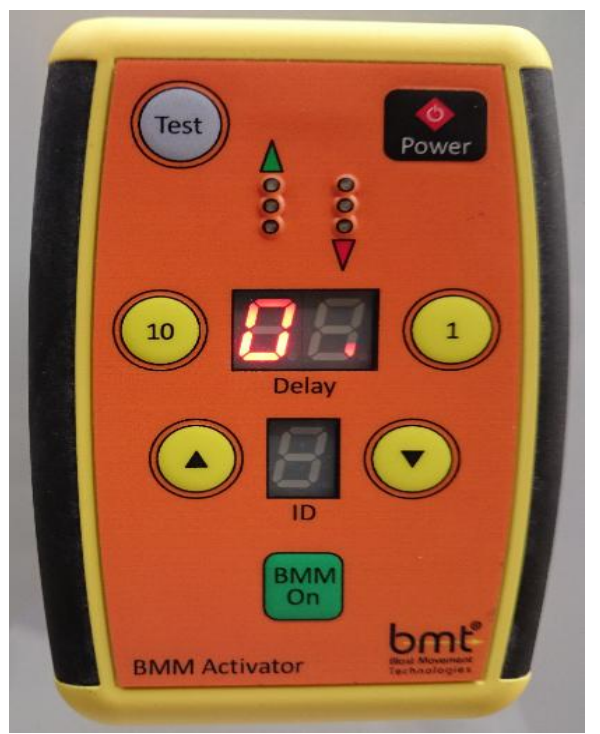

Fig. 4 Blast Movement Monitor (BMM®) Ball Activator (Anon., 2015)

\subsubsection{GP5200 BMM® Detector}

The GP5200 BMM® Detector shown in Fig. 5 is designed specifically to detect and interpret the signal produced by the BMM® balls. The GP5200 control box is water and dust resistant but should not be immersed in water since the charging socket is not waterproof. The detector continuously displays the signal strength and can quickly locate local peak signals of a transmitting BMM ${ }^{\circledR}$ ball. Local peaks occur directly above each BMM® ball and the signal strength is used to determine the depth of the BMM® ball and therefore its position in 3-dimensional space. The BMM® ball's initial pre-blast position is recorded so a 3-dimension movement vector can be determined.

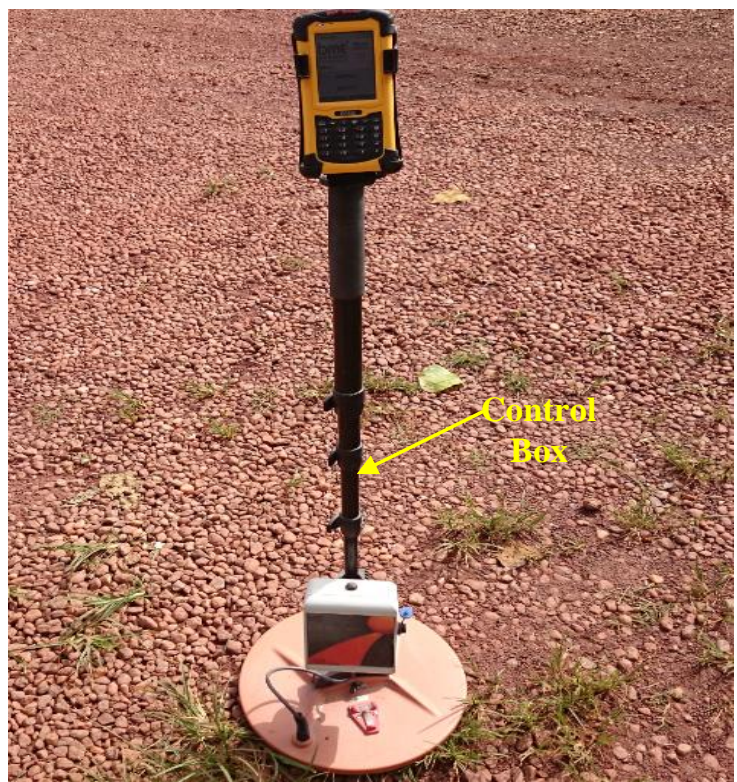

Fig. 5 Blast Movement Monitor (BMM®) Ball Detector (Anon., 2015) 


\subsubsection{Survey Equipment (GPS or Total Station)}

BMM drill holes collar positions are surveyed using GPS or Total station before blasting. After blasting, the mining engineer knowing the approximate direction of the blast movement from the initiation sequence moves in that direction with the BMM ${ }^{\circledR}$ detector until the strongest signal from the BMM ${ }^{\circledR}$ ball is detected. The mining engineer then marks the position after recoding the signal and the surveyor determines the post blast coordinates of the BMM® ball's location on the muckpile.

\subsubsection{Computer Software}

All numerical calculations and analysis are performed on a computer. The following software are used for processing and analysing the data: MS Excel, BMM Explorer and Datamine or Surpac.

\section{Resources and Methods Used}

\subsection{Materials}

The study utilised secondary data from files and documents of AngloGold Ashanti, Iduapriem Mine. Primary data was also collected from field studies using BMM instrument at AAIL. Processing and analysis of data were done using BMM Explorer and Datamine Software also from the Mine.

The following are the summary of data used for the analysis:

(i) Blast movement monitoring data for twenty-two (22) months (April 2013 to January 2015) (about 117 data sets);

(ii) Twenty seven (27) blasts were monitored at Ajopa pit on four (4) different benches. All the data for the 27 shots were used for horizontal and vertical movement analysis; and

(iii) Four (4) shots (one from each bench) made up of 8 flitches out of the 27 shots monitored were considered in the costbenefit analysis.

\subsection{Methods}

The BMM holes were measured to ascertain the depth of the holes and the BMM® balls were activated and placed into the drill holes. The BMM signal was then stored using the detector. After blasting, the post-blast $\mathrm{BMM} \AA$ positions in the muckpile were searched using the detector. Surveyors provided both the pre and post-blast $\mathrm{BMM} \AA$ coordinates.

The pre and post-blast data from the detector were downloaded into a computer. All the data were saved in .txt file format. The BMM Explorer software was provided with all the details of the blast such as:

(i) Blast ID;

(ii) Blast date;

(iii) Hole diameter $(\mathrm{mm})$;

(iv) Bench height (m);

(v) Spacing and burden (m);

(vi) Delay timing (ms);

(vii) Powder factor $\left(\mathrm{kg} / \mathrm{m}^{3}\right)$;

(viii) Type of explosive;

(ix) Type of initiation;

(x) Rock type;

(xi) Hole depth (m); and

(xii) Stemming length (m)

\section{Results and Discussion}

Shot "Blast_1607_20" is used as an example to illustrate results from the data collection. The shot properties listed from 1 to 12 in Section 2.2 were fed into the BMM Explorer software for rock movement analysis. Fig. 6 shows a window from the BMM Explorer software of the blast properties or input parameters of Shot 20 on 1607 Reduced Level (RL). Table 1 shows the summary of blast movement measurement of Shot 20. Fig. 7 shows the output of Shot 20, indicating the movement of the BMM® balls. Fig. 8 shows the plan view of horizontal movement of the BMM® balls. A total of eight (8) BMM ${ }^{\circledR}$ balls were placed in this pattern and all of them were detected after the blast. This shows $100 \%$ recovery. For the whole study average BMM® balls recovery was $96 \%$.

Fig. 9 illustrates the vertical movement of Shot 20 . Since there were two reefs in Shot 20, the center line for the shot was placed at the centre of the reefs hence the BMM ${ }^{\circledR}$ s from each reef could be seen moving towards each other as echelon (christmas tree) tie up was used. Blasting was done on $6 \mathrm{~m}$ bench and excavation was done in $3 \mathrm{~m}$ flitches. Two BMM® balls were dropped into a hole. The first BMM ${ }^{\circledR}$ ball was installed around $4.5 \mathrm{~m}$ depth for detecting the bottom flitch movement while the other BMM ${ }^{\circledR}$ ball was installed around $1.5 \mathrm{~m}$ depth (after back filling with stemming material) for monitoring the movement of the top flitch.

The entire Ajopa blast monitoring data were exported from the BMM Explorer into MS Excel for horizontal and vertical movement analysis. A scatter diagram was then plotted from the data set as shown in Fig. 10 and Fig. 11. 


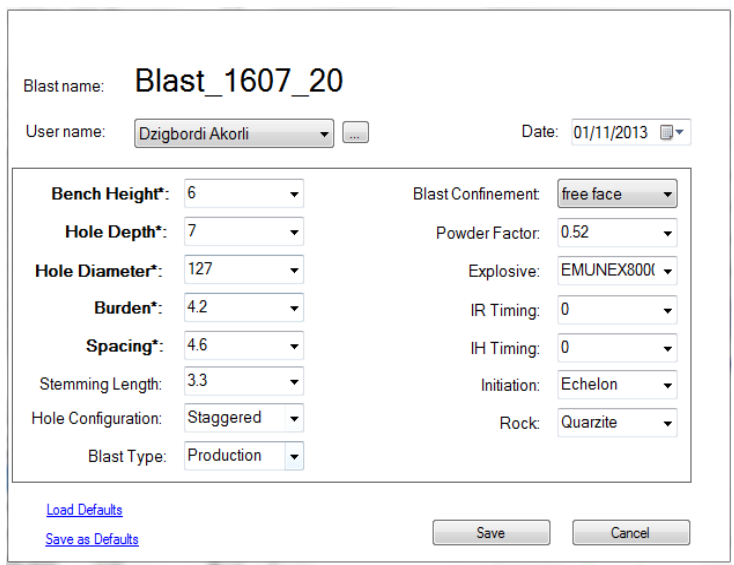

Fig. 6 Blast Properties from BMM Assistant Software

Table 1 Summary of the Blast Movement Measurement for Shot 20

\begin{tabular}{|c|c|c|c|c|c|c|c|c|c|c|c|}
\hline BMM \# & $\begin{array}{c}\text { Initial } \\
\text { Depth } \\
\text { (m) }\end{array}$ & \begin{tabular}{|c} 
Horiz \\
Distance \\
(m)
\end{tabular} & \begin{tabular}{|c|} 
Vert. \\
Distanc \\
(m)
\end{tabular} & \begin{tabular}{|c|} 
3D \\
Distance \\
(m)
\end{tabular} & \begin{tabular}{|c|}
$\begin{array}{c}\text { Direction } \\
(\mathrm{deg})\end{array}$ \\
\end{tabular} & $\begin{array}{c}\text { Inclination } \\
(\mathrm{m})\end{array}$ & \begin{tabular}{|c} 
Initial \\
Surface \\
RL
\end{tabular} & \begin{tabular}{|c|c|} 
Final \\
Surface \\
RL \\
\end{tabular} & \begin{tabular}{|c|} 
Initial \\
BMM \\
RL
\end{tabular} & $\begin{array}{c}\text { Final } \\
\text { BMM RL }\end{array}$ & \begin{tabular}{|c} 
Post \\
Blast \\
Survey \\
\end{tabular} \\
\hline 1-G & 4.0 & 2.7 & 1.3 & 2.9 & 42.8 & 25.3 & \begin{tabular}{|l|l}
1612.8 \\
\end{tabular} & \begin{tabular}{|l|l}
1615.1 \\
\end{tabular} & \begin{tabular}{|l|l|}
1608.8 \\
\end{tabular} & 1610.1 & B-G \\
\hline $2-R$ & 1.5 & 2.0 & 2.1 & 2.9 & 45.9 & 46.2 & \begin{tabular}{|l|l}
1612.8 \\
\end{tabular} & \begin{tabular}{|l|}
1615.1 \\
\end{tabular} & \begin{tabular}{|l|l|l}
1611.3 \\
\end{tabular} & 1613.4 & $A-R$ \\
\hline 3-0 & 4.2 & 2.1 & 0.2 & 2.1 & 38.7 & 5.3 & \begin{tabular}{|l|l}
1612.7 \\
\end{tabular} & \begin{tabular}{|l|l}
1613.8 \\
\end{tabular} & \begin{tabular}{|l|l}
1608.5 \\
\end{tabular} & 1608.7 & D- 0 \\
\hline 4-Y & 1.6 & 1.5 & 1.0 & 1.8 & 49.3 & 34.6 & \begin{tabular}{|l}
1612.7 \\
\end{tabular} & 1613.6 & \begin{tabular}{|l|l}
1611.1 \\
\end{tabular} & 1612.1 & C-Y \\
\hline $5-\mathrm{G}$ & 4.5 & 4.3 & 1.1 & 4.4 & 345.9 & 14.6 & \begin{tabular}{|l|l}
1612.7 \\
\end{tabular} & \begin{tabular}{|l|l}
1614.9 \\
\end{tabular} & \begin{tabular}{|l|l}
1608.2 \\
\end{tabular} & 1609.3 & E-G \\
\hline $6-0$ & 1.5 & 5.5 & 3.8 & 6.7 & 345.1 & 34.7 & \begin{tabular}{|l|l}
1612.7 \\
\end{tabular} & \begin{tabular}{|l|l}
1613.8 \\
\end{tabular} & \begin{tabular}{|l|l|}
1611.2 \\
\end{tabular} & 1613.4 & F-0 \\
\hline 7-R & 4.4 & 3.2 & 0.3 & 3.2 & 356.4 & 5.9 & \begin{tabular}{|l}
1612.9 \\
\end{tabular} & 1614.3 & 1608.5 & 1608.8 & H-R \\
\hline $8-0$ & 1.4 & 2.6 & 1.0 & 2.8 & 348.8 & 21.4 & \begin{tabular}{|l|l}
1612.9 \\
\end{tabular} & \begin{tabular}{|l|l}
1614.0 \\
\end{tabular} & \begin{tabular}{|l|l|}
161.5 \\
\end{tabular} & 1612.5 & G-0 \\
\hline
\end{tabular}

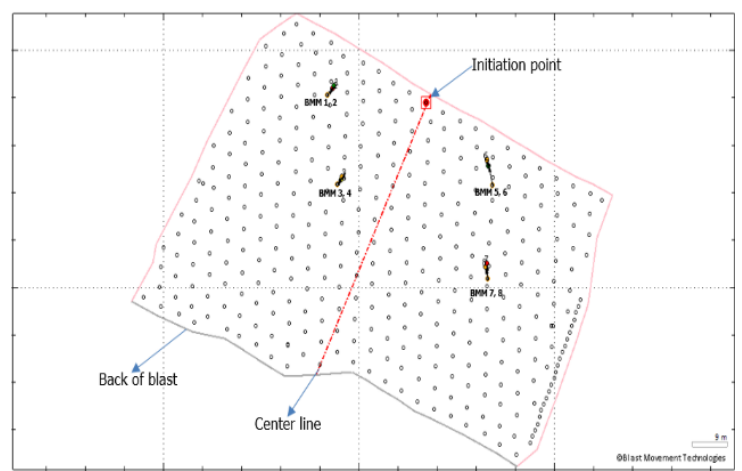

Fig. 7 Movement Vectors for Shot 20

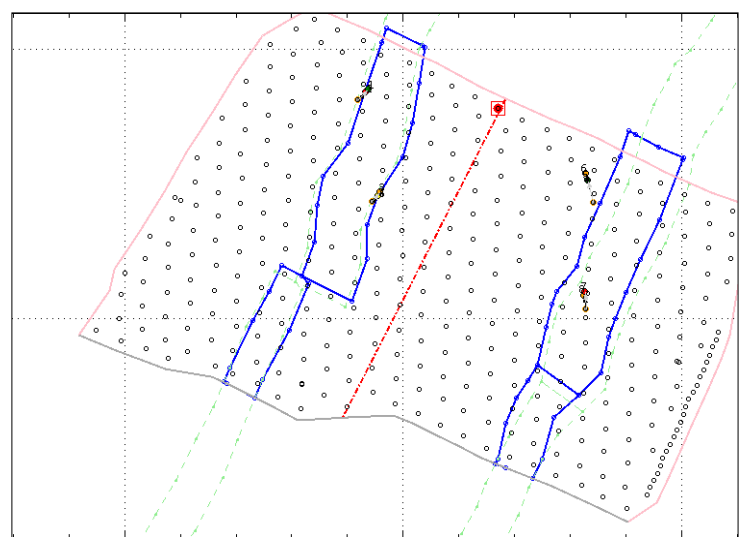

Fig. 8 Plan View of BMM $®$ Balls in Drill Holes
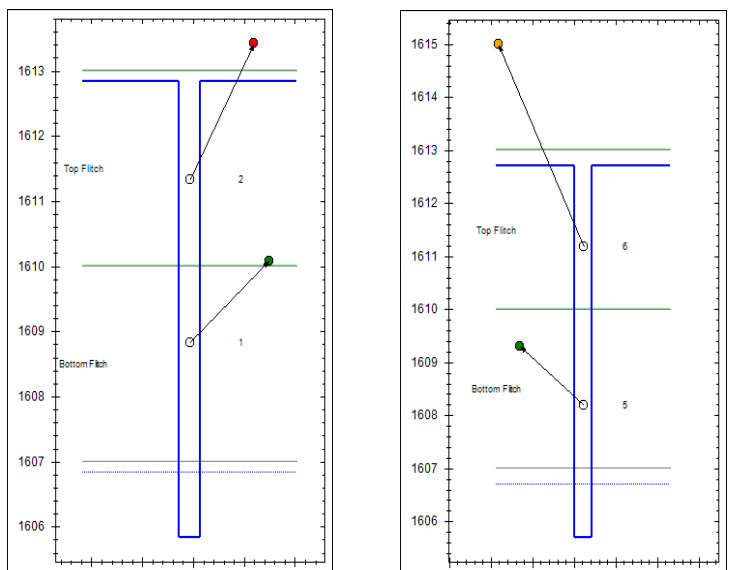

Fig. 9 Sectional View of BMM ${ }^{\circledR}$ Balls in Drill Holes

\subsection{Horizontal Movement Analysis}

A line of best fit was drawn through the scatter plots. A "D" shaped curve was observed indicating the bottom flitch moving farther than the top flitch. The average horizontal movement for bottom and top flitches were $3.0 \mathrm{~m}$ and $2.3 \mathrm{~m}$ respectively (see Fig. 10).

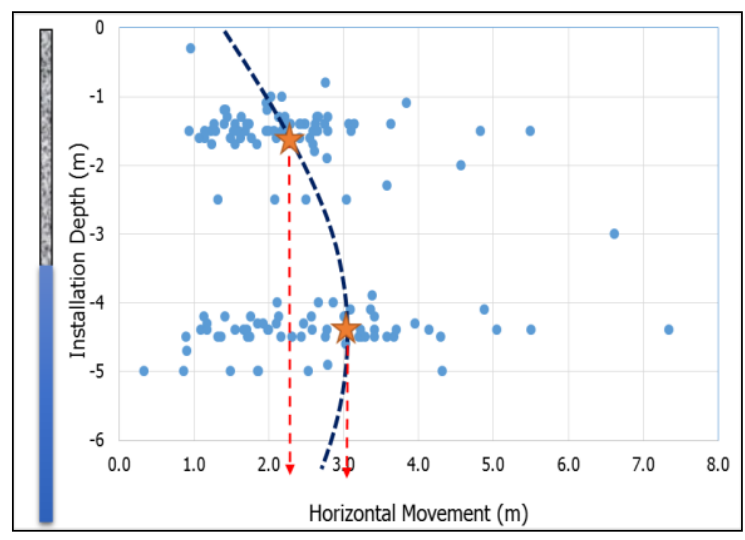

Fig. 10 Pictorial View of Horizontal Movement

\subsection{Vertical Movement Analysis}

Similar exercise was carried out for the vertical movement. A line of best fit was drawn through the points. It should be noted that the heave or vertical movement was calculated from the top of the bench i.e., for Shot 20, the top of the bench was $1613 \mathrm{RL}$, hence material above $1613 \mathrm{RL}$ was classified as a heave. It could be observed that the top flitch moved higher than the bottom flitch. The average vertical movement for top and bottom flitches were $1.72 \mathrm{~m}$ and $0.9 \mathrm{~m}$ respectively (see Fig. 11). 


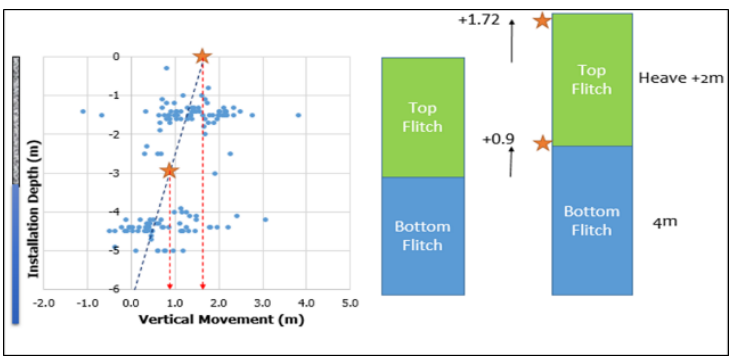

Fig. 11 Vertical Movement Interpretation (not drawn to scale)

\subsection{Evaluating Ore Loss, Dilution and Misclassification}

The adjusted perimeter was exported from BMM Explorer into Datamine and this was superimposed with the pre ore perimeter as shown in Fig. 12. Assuming the pre ore perimeter was used in mining without adjustment, there would have been ore loss, dilution and misclassification. The regions defining ore loss, dilution and misclassification are illustrated in Fig. 13.

Ore loss, dilution and misclassification perimeters were evaluated using BMM Explorer (See Fig. 14). The results were also confirmed using Datamine software. The orebody at Iduapriem Ajopa pit is homogeneous (i.e. variation in grade is not erratic along strike) hence misclassication was ignored in the cost-benefit analysis. Table 2 to 5 show the summary of evaluation of the eight flitches for the four (4) shots analysed.

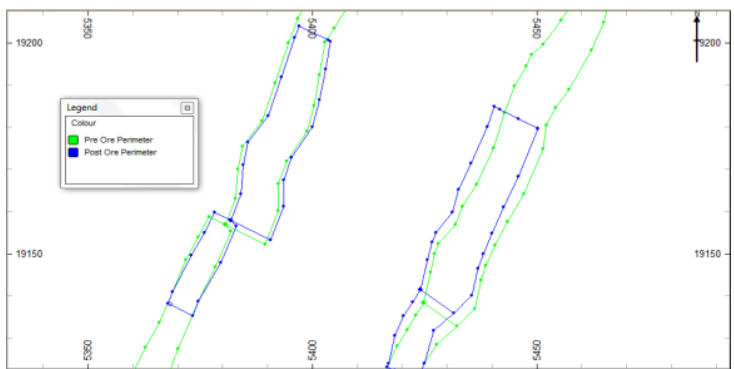

Fig. 12 Plan view of Pre and Post ore Perimeter Superimposed

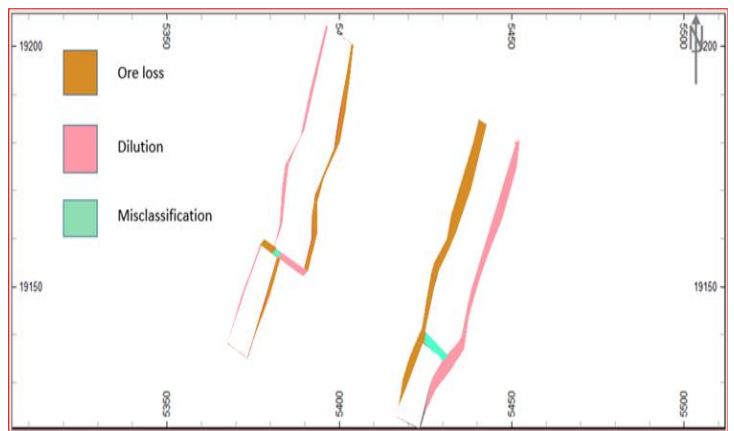

Fig. 13 Digitised Perimeters of Ore Loss, Dilution and Misclassification using Datamine Software

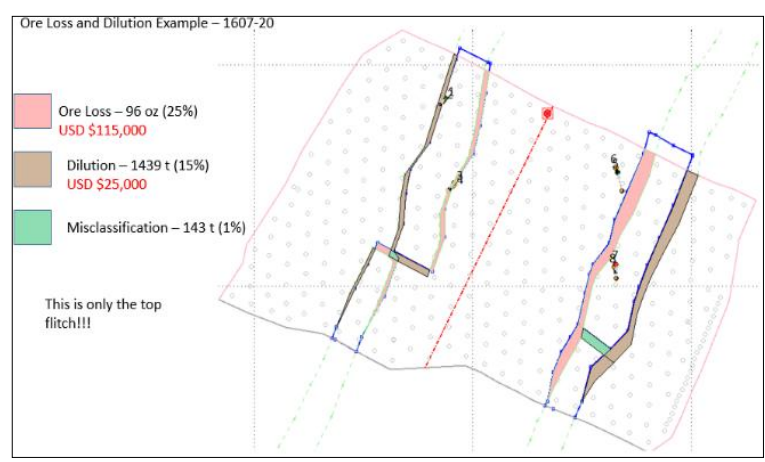

Fig. 14 Calculation of Ore Loss, Dilution and Misclassification using BMM Explorer

Table 2 Ore Loss and Dilution Summary (Blast_1607_20)

\begin{tabular}{|c|c|c|c|c|c|c|c|c|}
\hline \multicolumn{9}{|l|}{ Blast_1607_20_Top_Flitch } \\
\hline \multirow{2}{*}{ Block Name } & \multicolumn{2}{|c|}{ In Situ } & \multicolumn{2}{|c|}{ Loss } & \multicolumn{2}{|c|}{ Dilution } & \multicolumn{2}{|c|}{ Misclassification } \\
\hline & (t) & $(g / t)$ & (t) & $(\%)$ & (t) & $(\%)$ & (t) & $(\%)$ \\
\hline Block_12_Top Flitch & 1010 & 1.62 & 376 & 37 & 159 & 16 & 0 & 0 \\
\hline Block_13_Top Flitch & 3919 & 1.24 & 1285 & 33 & 795 & 20 & 119 & 3 \\
\hline Block_14_Top Flitch & 1129 & 1.09 & 417 & 37 & 72 & 6 & 0 & 0 \\
\hline Block_15_Top Flitch & 3713 & 1.16 & 446 & 12 & 413 & 11 & 24 & 1 \\
\hline Tota/Weighted Average & 9771 & 1.23 & 2524 & 26 & 1439 & 15 & 143 & 1 \\
\hline \multicolumn{9}{|c|}{ Blast_1607_20_Bottom_Flitch } \\
\hline \multirow{2}{*}{ Block Name } & \multicolumn{2}{|c|}{ In Situ } & \multicolumn{2}{|c|}{ Loss } & \multicolumn{2}{|c|}{ Dilution } & \multicolumn{2}{|c|}{ Misclassification } \\
\hline & (t) & $(\mathrm{g} / \mathrm{t})$ & (t) & $(\%)$ & (t) & $(\%)$ & (t) & $(\%)$ \\
\hline Block_12_Bottom Flitch & 1010 & 1.62 & 342 & 34 & 151 & 15 & 0 & 0 \\
\hline Block_13_Bottom Flitch & 3919 & 1.24 & 1136 & 29 & 700 & 18 & 143 & 4 \\
\hline Block_14_Bottom Flitch & 1121 & 1.09 & 432 & 39 & 64 & 6 & 0 & 0 \\
\hline Block_15_Bottom Flitch & 3721 & 1.16 & 479 & 13 & 485 & 13 & 40 & 1 \\
\hline TotaVWeighted Average & 9771 & 1.23 & 2390 & 24 & 1399 & 14 & 183 & 2 \\
\hline
\end{tabular}


Table 3 Ore Loss and Dilution Summary (Blast_1601_13)

\begin{tabular}{|c|c|c|c|c|c|c|c|c|}
\hline \multicolumn{9}{|l|}{ Blast_1601_13_Top } \\
\hline \multirow{2}{*}{ Block Name } & \multicolumn{2}{|c|}{ In Situ } & \multicolumn{2}{|c|}{ Loss } & \multicolumn{2}{|c|}{ Dilution } & \multicolumn{2}{|c|}{ Misclassification } \\
\hline & (t) & $(g / t)$ & (t) & $(\%)$ & (t) & $(\%)$ & (t) & $(\%)$ \\
\hline Block_11_Top Flitch & 326 & 1.41 & 605 & 186 & 127 & 39 & 87 & 27 \\
\hline B lock_12_Top Flitch & 2457 & 1.12 & 780 & 32 & 501 & 20 & 0 & 0 \\
\hline Tota/Weighted Average & 2783 & $\mathbf{1 . 1 5}$ & 1384 & 50 & 628 & 23 & 87 & 3 \\
\hline \multicolumn{9}{|l|}{ Blast_1601_13_Bottom } \\
\hline \multirow{2}{*}{ Block Name } & \multicolumn{2}{|c|}{ In Situ } & \multicolumn{2}{|c|}{ Loss } & \multicolumn{2}{|c|}{ Dilution } & \multicolumn{2}{|c|}{ Misclassification } \\
\hline & (t) & $(g / t)$ & $(\mathbf{t})$ & $(\%)$ & (t) & $(\%)$ & (t) & $(\%)$ \\
\hline Block_11_Bottom Flitch & 318 & 1.41 & 180 & 56 & 95 & 30 & 167 & 53 \\
\hline Block_12_Bottom Flitch & 2441 & 1.12 & 1032 & 42 & 644 & 26 & 0 & 0 \\
\hline Tota/Weighted Average & 2759 & $\mathbf{1 . 1 5}$ & 1211 & 44 & 739 & 27 & 167 & 6 \\
\hline
\end{tabular}

Table 4 Ore Loss and Dilution Summary (Blast_1631_20)

\begin{tabular}{|c|c|c|c|c|c|c|c|c|}
\hline \multicolumn{9}{|l|}{ Blast_1631_20_Top_Flitch } \\
\hline \multirow{2}{*}{ Block Name } & \multicolumn{2}{|c|}{ In Situ } & \multicolumn{2}{|c|}{ Loss } & \multicolumn{2}{|c|}{ Dilution } & \multicolumn{2}{|c|}{ Misclassification } \\
\hline & (t) & $(g / t)$ & (t) & $(\%)$ & (t) & $(\%)$ & (t) & $(\%)$ \\
\hline Block_11_Top Flitch & 1829 & 1.62 & 280 & 15 & 151 & 8 & 103 & 6 \\
\hline B lock_12_Top Flitch & 3021 & 1.62 & 208 & 7 & 215 & 7 & 0 & 0 \\
\hline Tota/Weighted Average & 4850 & 1.62 & 488 & 10 & 366 & 8 & 103 & 2 \\
\hline \multicolumn{9}{|l|}{ Blast_1601_13_Bottom } \\
\hline \multirow{2}{*}{ Block Name } & \multicolumn{2}{|c|}{ In Situ } & \multicolumn{2}{|c|}{ Loss } & \multicolumn{2}{|c|}{ Dilution } & \multicolumn{2}{|c|}{ Misclassification } \\
\hline & (t) & $(g / t)$ & (t) & $(\%)$ & (t) & $(\%)$ & (t) & $(\%)$ \\
\hline Block_11_Bottom Flitch & 1836 & 1.62 & 281 & 15 & 143 & 8 & 175 & 10 \\
\hline Block_12_Bottom Flitch & 3156 & 1.62 & 176 & 6 & 366 & 12 & 8 & 0 \\
\hline Tota/Weighted Average & 4993 & 1.62 & 457 & 9 & 509 & 10 & 183 & 4 \\
\hline
\end{tabular}

Table 5 Ore Loss and Dilution Summary (Blast_1637_05)

\begin{tabular}{|c|c|c|c|c|c|c|c|c|}
\hline \multicolumn{9}{|l|}{ Blast_1607_20_Top_Flitch } \\
\hline \multirow{2}{*}{ Block Name } & \multicolumn{2}{|c|}{ In Situ } & \multicolumn{2}{|c|}{ Loss } & \multicolumn{2}{|c|}{ Dilution } & \multicolumn{2}{|c|}{ Misclassification } \\
\hline & (t) & $(g / t)$ & (t) & $(\%)$ & (t) & $(\%)$ & (t) & $(\%)$ \\
\hline Block_13_Top Flitch & 3291 & 1.62 & 1217 & 37 & 1010 & 31 & 32 & 1 \\
\hline Block_14_Top Flitch & 3514 & 1.62 & 901 & 26 & 938 & 27 & 0 & 0 \\
\hline Block_15_Top Flitch & 56 & 1.62 & 0 & 0 & 0 & 0 & 0 & 0 \\
\hline Tota/Weighted Average & 6861 & 1.62 & 2118 & 31 & 1948 & 28 & 32 & $\mathbf{0}$ \\
\hline \multicolumn{9}{|l|}{ Blast_1607_20_Bottom_Flitch } \\
\hline \multirow{2}{*}{ Block Name } & \multicolumn{2}{|c|}{ In Situ } & \multicolumn{2}{|c|}{ Loss } & \multicolumn{2}{|c|}{ Dilution } & \multicolumn{2}{|c|}{ Misclassification } \\
\hline & (t) & $(g / t)$ & (t) & $(\%)$ & (t) & $(\%)$ & (t) & $(\%)$ \\
\hline Block_13_Bottom Flitch & 4317 & 2.00 & 1008 & 23 & 882 & 20 & 111 & 3 \\
\hline Block_14_Bottom Flitch & 4253 & 1.77 & 2163 & 51 & 2353 & 55 & 24 & 1 \\
\hline Block_15_Bottom Flitch & 326 & 1.76 & 0 & 0 & 32 & 10 & 0 & 0 \\
\hline Tota/Weighted Average & 8896 & 1.88 & 3171 & 36 & 3267 & 37 & 135 & 2 \\
\hline Grand Tota/Weighted Average & 50683 & 1.47 & 13744 & 27 & 10295 & 20 & 1034 & 2 \\
\hline
\end{tabular}




\subsection{Cost Benefit Analysis}

Table 5 presents the total ore loss and dilution tonnages for the four (4) shots employed in the cost-benefit analysis while Table 6 outlines the estimation of the net revenue from employing the BMM system.

Assuming the monitoring was not carried out, the ore loss material would have been mined and sent to waste dump, but because of the BMM system, the material was "salvaged" to the ROM Pad. The revenue accrued from treating this material is estimated as $\$ 724800$. The differential cost incurred for moving the material to the ROM pad instead of waste dump is estimated as \$9 621 using a differential unit cost of $\$ 0.7 / \mathrm{t}$. Thus the benefit for salvaging the ore loss material by employing the BMM system is given by the revenue from the treated material less the differential cost which gives $\$ 715179$ as shown in Table 6.

Similarly, assuming the pre ore outline were used in mining, $10295 \mathrm{t}$ of diluted ore would have ended up at the processing plant thereby increasing the processing cost by $\$ 247080$ using a unit processing cost of $\$ 24 / \mathrm{t}$. The revenue that would have been obtained for treating this material is estimated as \$99 600 using the grade of the diluted ore as half of Ajopa pit low grade cut-off of 0.53 $\mathrm{g} / \mathrm{t}$ i.e. $0.27 \mathrm{~g} / \mathrm{t}$. The cost saving for not transporting the material to the ROM pad for processing but moving the material to the waste dump is estimated as \$7 207 using a unit differential cost of \$0.7/t. Thus, the net revenue for not treating the diluted ore is given by the sum of the processing cost (which wasn't incurred thus a cost saving) and the differential cost saving of sending the material to the waste dump less the revenue that would have been obtained which gives $\$ 154687$ as presented in Table 6. The total revenue for employing the BMM system to cater for ore loss and dilution is estimated as $\$ 869866$ from the four (4) shots used for the analysis (see Table 6).

Table 7 shows the cost estimation input parameters for employing the BMM system for the four (4) shots used in the cost-benefit analysis. The total cost is estimated as $\$ 116031$ as shown in Table 8. With the net revenue estimated as $\$ 869866$ in Table 6, the net benefit for employing the BMM system using the four (4) shots for the analysis within the study period gives $\$ 753835$ which translates into a return on investment of $650 \%$. The use of the BMM system is thus beneficial to the Mine even in terms of its financial implication.
Table 6 Net Revenue Estimation

\begin{tabular}{|c|c|c|c|c|c|c|c|}
\hline \multicolumn{8}{|l|}{ Ore Loss } \\
\hline \multirow{2}{*}{$\begin{array}{l}\text { Total Ore } \\
\text { Loss } \\
\text { (t) }\end{array}$} & \multirow{2}{*}{$\begin{array}{c}\text { Grade } \\
(\mathrm{g} / \mathrm{t})\end{array}$} & \multirow{2}{*}{$\begin{array}{c}\text { Ounces } \\
\text { (oz) }\end{array}$} & \multirow{2}{*}{$\begin{array}{c}\text { Recovery } \\
\text { at } 93 \% \\
(\mathbf{o z})\end{array}$} & \multirow{2}{*}{$\begin{array}{c}\text { Revenue @ } \\
\$ 1 \text { 200/oz } \\
\text { (\$) }\end{array}$} & \multirow{2}{*}{\multicolumn{2}{|c|}{$\begin{array}{c}\text { Differential Cost @ } \\
\$ 0.7 / \mathrm{t} \\
(\$)\end{array}$}} & \multirow{2}{*}{$\begin{array}{l}\text { Net } \\
\text { Revenue } \\
(\$)\end{array}$} \\
\hline & & & & & & & \\
\hline 13744 & 1.47 & 650 & 604 & +724800 & & & +715 179 \\
\hline \multicolumn{8}{|l|}{ Dilution } \\
\hline \multirow{2}{*}{$\begin{array}{c}\text { Total } \\
\text { Diluted Ore } \\
\text { (t) }\end{array}$} & \multirow[b]{2}{*}{$\begin{array}{c}\text { Grade } \\
(\mathrm{g} / \mathrm{t})\end{array}$} & & \multirow[b]{2}{*}{$\begin{array}{l}\text { Recovery } \\
\text { at 93\% } \\
(\text { oz) }\end{array}$} & \multirow[b]{2}{*}{$\begin{array}{c}\text { Revenue @ } \\
\$ 1 \text { 200/oz } \\
\text { (\$) }\end{array}$} & \multicolumn{2}{|c|}{ Differential|Processing } & \multirow{2}{*}{$\begin{array}{c}\text { Net } \\
\text { Revenue } \\
(\$)\end{array}$} \\
\hline & & $\begin{array}{l}\text { Dunces } \\
\text { (oz) }\end{array}$ & & & $\begin{array}{c}\text { Cost @ } \\
\$ 0.7 / \mathrm{t} \\
(\$)\end{array}$ & \begin{tabular}{|c|} 
Cost at \\
$\$ 24 / \mathrm{t}$ \\
$(\$)$
\end{tabular} & \\
\hline 10295 & 0.27 & 89 & 83 & -99600 & +7207 & +247080 & +154687 \\
\hline \multicolumn{7}{|c|}{ Total Net Revenue for Using BMM System } & 869866 \\
\hline
\end{tabular}

Table 7 Cost Estimation Input Parameters

\begin{tabular}{|l|c|}
\hline Inputs Parameters & Unit Per Period \\
\hline $\begin{array}{l}\text { Total Cost of Light Package } \\
\text { BMM System }\end{array}$ & $\$ 114,490 / \mathrm{yr}$ \\
\hline Number of Blasts & 4 \\
\hline Total Number of BMMs & 26 \\
\hline Average No of Holes per Blast & 3 \\
\hline Depth of Holes & $4.5 \mathrm{~m}$ \\
\hline Drilling Cost & $\$ 14.47 / \mathrm{m}$ \\
\hline Mining Engineer Labour Cost & $\$ 20 / \mathrm{hr}$ \\
\hline Surveyor Labour Cost & $\$ 20 / \mathrm{hr}$ \\
\hline Time to Install BMMs & $2 \mathrm{hr} / \mathrm{blast}$ \\
\hline Time to Detect BMMs & $1.5 \mathrm{hr} / \mathrm{blast}$ \\
\hline Time Spent by Surveyors & $2 \mathrm{hr} / \mathrm{blast}$ \\
\hline Number of Mining Engineers & $2 / \mathrm{blast}$ \\
\hline Number of Surveyors & $2 / \mathrm{blast}$ \\
\hline BMM Software & $0.5 \mathrm{hr} / \mathrm{blast}$ \\
\hline
\end{tabular}

Table 8 Cost-Benefit Estimation

\begin{tabular}{|l|c|}
\hline \multicolumn{2}{|c|}{ Total Cost of Monitoring and Adjusting 4 shots } \\
\hline $\begin{array}{l}\text { Total Annual Cost of Ownership (BMM } \\
\text { System) }\end{array}$ & $\$ 114490$ \\
\hline Total Drilling Cost & $\$ 781$ \\
\hline Total Mining Engineer Labour Cost & $\$ 600$ \\
\hline Total Surveyor Labour Cost & $\$ 160$ \\
\hline Total Cost (A) & $\mathbf{\$ 1 1 6 0 3 1}$ \\
\hline \multicolumn{2}{|c|}{} \\
\hline Net Revenue (B) (See Table 6) & $\mathbf{\$ 8 6 9 8 6 6}$ \\
\hline Net Benefit (C = B - A) & $\mathbf{\$ 7 5 3 ~ 8 3 5}$ \\
\hline Return on Investment (C/A * 100\%) & $\mathbf{6 5 0 \%}$ \\
\hline
\end{tabular}

\section{Conclusions and Recommendations}

\subsection{Conclusions}

From the study and analysis, it can be concluded that:

(i) The average horizontal movement of the entire blast monitored at Ajopa is such that the bottom flitch of the blasts moved farther than the top; average bottom flitch movement was $3.0 \mathrm{~m}$ and average top flitch movment was $2.3 \mathrm{~m}$.

(ii) The average vertical movement or the heave of the entire blast monitored is such that the 
top flitch of the blasts moved farther than the bottom flitch; average top flitch movement was $1.72 \mathrm{~m}$ and average bottom flitch movement was $0.9 \mathrm{~m}$.

(iii) The cost of monitoring four (4) shots at Ajopa pit using the BMM system during the study period was $\$ 116031$ and the revenue was $\$ 869866$ which implies, Iduapriem Mine made a savings of $\$ 753835$ which amounted to $650 \%$ Return on Investment (ROI).

(iv) Thus, the benefit of employing the BMM system at Iduapriem Mine has a positive financial implication.

\subsection{Recommendations}

(i) From the conclusions it is recommended that:

(ii) Implementation of the BMM system at Iduapriem Mine should be continued and if possible every shot containing ore should be monitored;

(iii) Dedicated team made up of at least two Engineers (Geological or/and Mining) should be trained specially for the task;

(iv) High precision GPS should be added to the detector instrument to make survey of pre and post BMM points easier and faster; and

(v) Finally, further research should be conducted which will consider sampling the ore loss and dilution regions within the muckpile to confirm the grades of these materials.

\section{Acknowledgements}

The authors wish to express their sincere gratitude to the BMT team at AngloGold Ashanti Iduapriem Mine; Kofi Poku Osei, Augustine Acheampong and Amina Mma Al-Hassan for their unflinching support. We are also grateful to the management of AngloGold Ashanti Iduapriem Ltd. for permitting us to use their data for this paper.

\section{References}

Adam, M. and Thornton, D. M. (2004), "A New Technology for Measuring Blast Movement", Proceedings of Innovative Mineral Developments - Achievements in a Changing World, Australasian Institute of Mining and Metallurgy, Sydney Branch, unpaginated.

Anon. (2013), “Iduapriem Competent Person's Report”, Mineral Resources, No. 52, 52 pp.

Anon. (2015), “GP5200_Detector_Manual 1406_A4", www.bmt.com. $\bar{a} u$. Accessed: 10th March, 2015.

Baffoe, S. K. (2004), "Open Pit Mine Planning and Design”, MSc Thesis Report, Western
University College of KNUST, Tarkwa, Ghana, pp. 4 - 6, 29.

Engmann, E., Ako, S., Bisiaux, B., Rogers, W. and Kanchibotla, S. (2013), "Measurement and Modelling of Blast Movement to Reduce Ore Losses and Dilution at Ahafo Gold Mine in Ghana", Ghana Mining Journal, pp. 27-36.

La Rosa, D and Thornton, D. (2011) "Blast Movement Modelling and Measurement", Proceedings of the 35th APCOM Symposium, Wollongong, NSW.

Little, T. N. and Van Rooyen, F. (1988), "The Current State of the Art of Grade Control Blasting in the Eastern Goldfields", The Aus. IMM Explosives in Mining Workshop, Melbourne, Victoria, pp. 87-95.

Loeb, J. and Thornton, D. (2014), “A Cost Benefit Analysis to Explore the Optimal Number of Blast Movement Monitoring Locations", Proceedings of the Ninth International Mining Geology Conference, Adelaide, SA.

Lucas, R. and Nies, D. (1990), "Improving Fragmentation and Ore Displacement Control", Proceedings of the Sixteenth Conference on Explosives and Blasting Technique, The Society of Explosives Engineers. Orlando, Florida, pp. 409- 422.

Taylor, S. L. (1995), "Blast Induced Movement and its Effects on Grade Dilution at the Coeur Rochester Mine", MSc Thesis, Department of Mining Engineering, Mackay School of Mines, Reno, Nevada, 237 pp.

Thornton, D., Sprott, D. and Brunton, I. (2005), "Measuring Blast Movement to Reduce Ore Loss and Dilution", Proceeding of 31st Annual Conference on Explosives \& Blasting Technique, Cleveland, OH, USA.

Thornton, D. (2009a), "The Implications of BlastInduced Movement to Grade Control", Proceedings of the Seventh International Mining Geology Conference, Perth WA, Australia, pp. 287-300.

Thornton, D, (2009b), "The Application of Electronic Monitors to Understand Blast Movement Dynamics and Improve Blast Designs", Proceedings of the Ninth International Symposium on Rock Fragmentation by Blasting - Fragblast 9, (ed: J A Sanchidrian), Taylor and Francis Group: London, pp. 287-399.

Yang, R. L. and Kavetsky, A. (1989), "A Two Dimensional Kinematic Model for Predicting Muckpile Shape in Bench Blasting", International Journal of Mining and Geological Engineering, London, Chapman and Hall, pp. 209-226.

Yennamani, A. L. (2010), "Blast Induced Rock Movement Measurement for Grade Control at the Phoenix Mine”, MSc Thesis, Department of Mining Engineering, Mackay School of Mines, Reno, Nevada, 123 pp. 
Zhang, S. (1994), "Rock Movement due to Blasting and its Impact on Ore Grade Control in Nevada Open Pit Gold Mines", MSc Thesis, Department of Mining Engineering, Mackay School of Mines, Reno, Nevada, 168 pp.

Zhang, S., Gilbride, L. J., Mousset-Jones, P. and Daemen, J. K., (1994), "Blast Rock Movement and its Impact on Ore Grade Control at Rain Mine Newmont Gold Company", Proceedings of 3rd International Symposium on Mine Planning and Equipment Selection, Istanbul, Turkey, pp. 713-719.

\section{Authors}

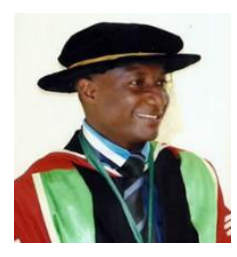

Peter Arroja Eshun obtained his BSc (Hons), $\mathrm{PgD}$, MPhil and $\mathrm{PhD}$ degrees in Mining Engineering from the University of Mines and Technology (UMaT), Tarkwa. He is currently an Associate Professor of Mining Engineering at UMaT and the Head of the Mining Engineering Department and the Vice Dean, School of Postgraduate Studies. He lectures in Mineral Project Evaluation, Principles of Management, Mineral Economics, Ocean and Alluvial Mining, and Computer Applications. His research interest is in the areas of Mine Economic and Financial Evaluation, Environmental Management, Socio-economic Impact Assessment, Mine Feasibility Studies, Computer Applications in Mining and Small Scale Mining.

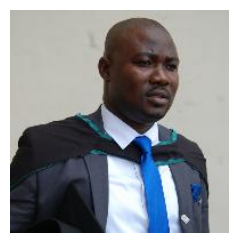

Dzigbordi Kwame Akorli holds a MSc in Mining Engineering from University of Mines and Technology (UMaT), Tarkwa, in 2015 and BSc in Geological Engineering from Kwame Nkrumah University of Science and Technology (KNUST), Ghana in 2004. He is currently a Geological Superintendent and Blast Monitoring Project Engineer at AngloGold Ashanti Iduapriem Mine. 